\title{
KONSELING GIZI DENGAN MEDIA BUKU SAKU BERPENGARUH TERHADAP PENGETAHUAN DAN INTAKE NATRIUM PADA PASIEN CHRONIC KIDNEY DISEASE (CKD) DI RS ROEMANI SEMARANG
}

\section{NUTRITION COUNSELING WITH POCKET BOOK MEDIA INFLUENCES KNOWLEDGE AND INTAKE OF SODIUM IN CHRONIC KIDNEY DISEASE (CKD) PATIENTS AT ROEMANI HOSPITAL SEMARANG}

\author{
Dominico Surya ${ }^{1}$, Wiwik Wijaningsih ${ }^{2}$, Yuniarti $^{3}$, Meirina Dwi L $^{4}$ \\ ${ }^{1}$ Mahasiswa Jurusan Gizi Politeknik Kesehatan Kemenkes Semarang \\ 2,3,4 Dosen Jurusan Gizi Politeknik Kesehatan Kemenkes Semarang
}

\section{ABSTRACT}

Background : Chronic Kidney Disease (CKD) is a protection program for a period of months or years. CKD patients who do the required $H D$, the amount of medication and normal sodium intake that are not working normally. Fluid and sodium intakes are one of the factors needed in the management of kidney failure to prevent complications due to edema, hypertension, and cardiovascular disease.

Objective : To find out nutritional counseling on knowledge and sodium intake in Chronic Kidney Disease Patients (CKD) who underwent Hemodialysis at Roemani Hospital Semarang.

Method : This study included a quasi experimental study with a Non Randomized Pretest Posttest Control Group research design. Sampling was 15 people in the treatment group and 15 people control group. Interventions provided include nutritional counseling with pocket book media. intake data collection was taken by interview using SQ-FFQ and knowledge data was taken by questionnaire. Results with paired t-test and independent $t$-test with a significance level of 0.05 .

Result : There is an effect of nutritional counseling with the media of pocket books on knowledge and sodium intake. Knowledge of respondents in the intervention group increased 22.33 and decreased sodium intake by 77.4 .

Conclusion : The provision of nutritional counseling using an influential pocket book increases knowledge and lowers intake compared to just giving a pocket book

Keywords : Sodium intake, knowledge, nutritional counseling, pocket book

\section{ABSTRAK}

Latar Belakang : Chronic Kidney Disease (CKD) adalah kehilangan fungsi ginjal secara progresif selama periode bulan atau tahun. Pasien CKD yang menjalankan HD perlu melakukan perubahan pola makan, jumlah obatobatan dan asupan natrium terkait dengan ginjal yang tidak berfungsi normal. Intake cairan dan natrium adalah salah satu faktor yang perlu diperhatikan dalam penatalaksanaan gagal ginjal untuk mencegah komplikasi akibatnya seperti edema, hipertensi, dan penyakit kardiovaskular.

Tujuan : Mengetahui pengaruh konseling gizi terhadap pengetahuan dan intake natrium pada Pasien Chronic Kidney Disease (CKD) yang menjalani Hemodialisis di RS Roemani Semarang.

Metode : Penelitian ini termasuk penelitian quasi experimental dengan desain penelitian Non Randomized Pretest Posttest Control Group. Pengambilan sampel sebanyak 15 orang kelompok perlakuan dan 15 orang kelompok kontrol. Intervensi yang diberikan berupa pemberian konseling gizi dengan media buku saku. pengumpulan data intake diambil dengan wawancara menggunakan SQ-FFQ dan data pengetahuan diambil dengan kuesioner. Hasil analisis dengan uji paired t-test dan uji independent $t$-test dengan tingkat kemaknaan 0,05 .

Hasil : Ada pengaruh pemberian konseling gizi dengan media buku saku terhadap pengetahuan dan intake natrium $(p=0,001$ dan $p=0,001)$. Pengetahuan responden kelompok intervensi meningkat $22,33 \%$ dan penurunan asupan natrium sebesar $77,4 \%$. 
Kesimpulan : Pemberian konseling gizi menggunakan buku saku berpengaruh meningkatkan pengetahuan dan menurunkan intake dibandingkan dengan hanya pemberian buku saku saja.

Kata kunci : Intake natrium, pengetahuan, konseling gizi, buku saku

\section{PENDAHULUAN}

Penyakit Ginjal Kronik (PGK) atau Chronic Kidney Disease (CKD) adalah kehilangan fungsi ginjal secara progresif selama periode bulan atau tahun. Setiap ginjal memiliki nefron yaitu filter kecil yang jumlahnya sekitar satu juta. Jika nefron rusak, ginjal tidak akan berfungsi, maka nefron yang sehat mendapatkan pekerjaan tambahan. Tetapi jika kerusakan terjadi secara terus menerus, semakin banyak nefron yang mati. Setelah titik tertentu, nefron yang tertinggal tidak bisa menyaring darah dengan baik ${ }^{1}$.

Global Burden of Disease menyatakan bahwa CKD merupakan peringkat 27 dalam daftar jumlah total kematian di seluruh dunia pada tahun 1990, namun meningkat menjadi peringkat 18 pada tahun $2010^{2}$. Populasi orang dewasa mengalami kerusakan ginjal dan setiap tahun jutaan orang meninggal akibat komplikasi yang berkaitan dengan CKD sebesar 8 sampai $10 \%{ }^{1}$. Menurut Indonesian Renal Registry (2014) jumlah pasien baru yang menjalani hemodialisis di Indonesia terus meningkat sejak tahun 2007 hingga 2014 sebanyak 4.977 hingga 17.193 orang.

Hasil Riset Kesehatan Dasar (Riskesdas) tahun 2013, menunjukkan prevalensi CKD berdasarkan diagnosis dokter di Indonesia sebesar $0,2 \%$, sedangkan provinsi Jawa Tengah sebesar $0,3 \%$. Presentase tersebut meningkat seiring dengan bertambahnya umur, meningkat tajam pada kelompok umur 35-44 tahun (0,3\%), diikuti umur 45-54 tahun $(0,4 \%)$ dan umur 55-74 tahun $(0,5 \%)$, tertinggi pada kelompok umur $\geq 75$ tahun $(0,6 \%)$. Berdasarkan data Persatuan Nefrologi Indonesia (PERNEFRI) jumlah pasien baru terus meningkat dari tahun ke tahun, pada tahun 2013 jumlahnya 15.128 penderita meningkat menjadi 17.193 penderita pada tahun 2014. Etiologi CKD dengan persentase terbesar, yaitu penyakit ginjal hipertensi (35\%), diikuti dengan nefropati diabetika (26\%), glomerulopati primer (12\%), nefropati obstruksi (8\%), pielonefritis kronis (7\%), lain-lain (6\%), nefropati asam urat (2\%), tidak diketahui (2\%), gagal polikistik (1\%), dan nefropati lupus (1\%).

Hemodialisis (HD) merupakan pengobatan ginjal yang menggunakan mesin untuk menyaring darah dari luar tubuh. Terapi ini tidak dapat menyembuhkan penyakit ginjal, melainkan membantu untuk meningkatkan umur hidup lebih lama. Pasien CKD yang menjalankan HD perlu melakukan perubahan pola makan, jumlah obatobatan dan asupan natrium terkait dengan ginjal yang tidak berfungsi normal ${ }^{3}$.

Gagal ginjal kronik didefinisikan sebagai perkembangaan gagal ginjal yang bersifat progresif dan ireversibel. Penyebab CKD antara lain diabetes, hipertensi, glomerulonefritis, infeksi, kista, obstruksi, dan penyakit sistemik. Penyakit tersebut menyebabkan kerusakan nefron yang progresif dan ireversibel ${ }^{4}$. Asupan cairan dan natrium adalah salah satu faktor yang perlu diperhatikan dalam penatalaksanaan gagal ginjal untuk mencegah komplikasi akibatnya seperti edema, hipertensi, dan penyakit kardiovaskular ${ }^{4}$. Penurunan laju filtrat glomerulus akan berdampak pada retensi natrium akibat penurunan kemampuan ginjal dalam mengompensasi dan mengekskresi kelebihan natrium di dalam tubuh dan menyebabkan terjadinya oliguria atau anuria. Faktor yang mempengaruhi keseimbangan natrium pada pasien hemodialisis yaitu kurang dari 2,4 gram/hari atau berkisar 1000-2300 mg/hari, dengan rekomendasi asupan cairan $750-1000 \mathrm{~mL}+$ jumlah urine

Ketidakpatuhan terhadap pembatasan intake natrium akan terjadi edema dan meningkatkan risiko pada kardiovaskuler dan hipertensi ${ }^{5}$. Pembatasan intake cairan dan natrium adalah aspek yang paling sulit untuk dipatuhi oleh pasien, di RSUD Arifin Achmad Pekanbaru 31,5\% sedangkan di RSUD Sukoharjo 45,16\% pasien tidak patuh pada pembatasan intake ${ }^{5,6}$. Kejadian edema di RS Roemani mencapai $25 \%$ dari total pasien CKD yang menjalani HD, hal ini merupakan akibat ketidakpatuhan pasien. Cara yang dapat digunakan untuk meningkatkan kepatuhan diet pembatasan intake pasien salah satunya dengan meningkatkan pengetahuan pasien. Konseling gizi merupakan salah satu upaya dalam meningkatkan pengetahuan dan kemampuan baik individu maupun keluarga sehingga memperoleh pengertian yang lebih baik tentang dirinya serta permasalahan yang dihadapi ${ }^{7}$. Pasien yang memiliki pengetahuan yang baik diharapkan dapat mengatasi masalah yang dihadapi, percaya diri dan mudah mengikuti anjuran dari tenaga kesehatan 5,8 . Ahli gizi sebagai salah satu tenaga kesehatan diharapkan mampu memberikan pelayanan rawat jalan dengan memberikan edukasi melalui 
konseling gizi karena dapat meningkatkan kepatuhan diet pasien ${ }^{9}$.

Berdasarkan uraian tersebut peneliti tertarik untuk melakukan konseling gizi pada Pasien CKD yang menjalani hemodialisis untuk meningkatkan pengetahuan dalam pembatasan intake natrium di RS Roemani. Rumah sakit ini dipilih karena merupakan rumah sakit rujukan dimana perawatan HD banyak dilakukan. Selain itu penelitian belum banyak dilakukan. Hasil penelitian diharapkan dapat memberikan informasi tentang buku saku sebagai media untuk konseling gizi bagi pasien CKD yang menjalani HD di rumah sakit tersebut.

\section{METODE}

Jenis penelitian ini merupakan penelitian quasi experiment, menggunakan rancangan non randomized pre-post test control grup design. Jumlah subjek penelitian sebanyak 30 orang yang sesuai kriteria inklusi yaitu berusia 18-65 tahun, menjalani hemodialisis 1 kali dalam seminggu, bersedia menjadi subjek penelitian, lama hemodialisis $<2$ tahun. ${ }^{10}$ Subjek penelitian terdiri dari kelompok treatment sebanyak 15 orang dan kelompok kontrol sebanyak 15 orang. Pengambilan sampel dilakukan dengan random sampling.

Penelitian ini dilakukan pada bulan Maret - Mei 2018 di RS Roemani Semarang selama kurun waktu 3 minggu

Instrumen penelitian yang digunakan meliputi kuesioner pengetahuan dan formulir SQFFQ. Pengetahuan dikategorikan baik jika skor $\geq$ $80 \%$ dan kurang jika skor $<80 \%$. Formulir SQ-FFQ yang digunakan untuk mengukur asupan makan dari subjek penelitian yang kemudian akan dibandingkan dengan kebutuhan dari masingmasing subjek penelitian $1000 \mathrm{mg}$. Asupan makan dikategorikan baik jika $\leq 100 \%$ kebutuhan dan lebih jika > 100\% dari kebutuhan.

Pengambilan data penelitian dilakukan dengan menjelaskan prosedur penelitian, lembar kesediaan menjadi subjek penelitian kemudian dilakukan penandatanganan dan dilakukan pengukuran intake natrium serta wawancara kuesioner pengetahuan.

Analisis univariat dilakukan untuk karakteristik subjek penelitian (umur, jenis kelamin, pendidikan terakhir dan pekerjaan), gambaran pengetahuan dan asupan natrium. Analisis bivariat digunakan untuk mengetahui pengaruh konseling gizi terhadap pengetahuan dan intake natrium. Uji yang digunakan uji Paired T-Test jika berdistribusi normal dan uji Wilcoxon jika tidak berdistribusi normal menggunakan.

\section{HASIL PENELITIAN}

Tabel 1. Distribusi Frekuensi Umur, Jenis Kelamin, Pendidikan Terakhir dan Pekerjaan Subjek Penelitian

\begin{tabular}{|c|c|c|c|c|c|c|}
\hline \multirow{2}{*}{ Variabel } & \multicolumn{2}{|c|}{$\begin{array}{l}\text { Treatment } \\
\end{array}$} & \multicolumn{2}{|c|}{ Kontrol } & \multirow[t]{2}{*}{ OR } & \multirow{2}{*}{$P$} \\
\hline & $\mathrm{N}$ & $\%$ & $\mathrm{~N}$ & $\%$ & & \\
\hline Umur & & & & & & \\
\hline $26-45$ tahun & 2 & 13,3 & 5 & 33,3 & $(0,51-20,3)$ & 0.857 \\
\hline 46-65 tahun & 13 & 86,7 & 10 & 66,7 & & \\
\hline Jenis Kelamin & & & & & & \\
\hline Perempuan & 7 & 46,7 & 6 & 40,0 & $(0,30-5,58)$ & 0.724 \\
\hline Laki-laki & 8 & 53,3 & 9 & 60,0 & & \\
\hline \multicolumn{7}{|l|}{ Pendidikan Terakhir } \\
\hline Tidak Sekolah/Tidak Tamat SD & 0 & 0 & 0 & 0,0 & & \\
\hline SD & 0 & 0 & 2 & 13,3 & & \\
\hline SMP & 8 & 53,3 & 4 & 26,7 & & \\
\hline SMA/SMK & 7 & 46,7 & 6 & 40,0 & & \\
\hline Perguruan Tinggi & 0 & 0 & 3 & 20,0 & & \\
\hline \multicolumn{7}{|l|}{ Pekerjaan } \\
\hline Guru & 0 & 0,0 & 0 & 0 & & \\
\hline PNS/ABRI/POLRI & 0 & 0,0 & 1 & 6,7 & & \\
\hline Karyawan Swasta & 0 & 0,0 & 4 & 26,7 & & \\
\hline Pedagang & 3 & 20,0 & 4 & 26,7 & & \\
\hline Tidak Bekerja & 12 & 80,0 & 6 & 40,0 & & \\
\hline Lain-lain & 0 & 0 & 0 & 0 & & \\
\hline
\end{tabular}

Sumber : Data Terolah

Berdasarkan tabel 1 dapat diketahui bahwa umur pasien antara 46-65 tahun mendominasi di setiap kelompok dan umur termuda yaitu 28 tahun sedangkan yang tertua 65 tahun. Hal ini sesuai dengan distribusi umur pasien HD Indonesia Renal Registry menunjukkan kelompok umur terbanyak sebanding antara umur 45 - 54 tahun dan 55 - 64 tahun yaitu 31,0\%, sedangkan pada tahun 2013 kelompok usia terbanyak ada pada kelompok 45 -54 sebanyak $30,26 \%{ }^{11}$. Berdasarkan hasil penelitian Hanum et al. (2015) dan Hakiki (2015) umur subjek penelitian pada pasien CKD yang menjalani Hemodialisis ratarata masuk dalam golongan dewasa akhir atau pada usia 45-60 tahun. Pada tabel 1 dapat dilihat bahwa $p$ value $=0,857$. Hasil ini menunjukan bahwa tidak ada perbedaan yang bermakna terhadap umur pada kelompok intervensi dan kelompok kontrol.

Total subjek penelitian berjenis kelamin perempuan yaitu 13 orang (43,3\%) dan laki-laki 17 orang $(56,7 \%)$. Pada masing-masing kelompok juga didominasi oleh laki-laki yaitu treatment 8 orang $(53,3 \%)$ dan kontrol 9 orang $(60 \%)$ yang dapat dilihat pada tabel 5 . Hasil penelitian ini menunjukkan bahwa subjek penelitian lebih banyak berjenis kelamin laki-laki. Namun, menurut Kring \& Crane 2009 dalam Umayah 2016 menyatakan bahwa jenis kelamin perempuan dan laki - laki serta pola hidup memiliki risiko yang sama penyebab terjadinyanya CKD dan harus menjalani HD. Pada tabel 1 dapat dilihat bahwa $p$ value $=0,724$. Hasil ini menunjukan bahwa tidak ada perbedaan yang bermakna terhadap jenis kelamin pada kelompok intervensi dan kelompok kontrol. $^{12}$

Subjek penelitian pada keseluruhan memiliki pendidikan terakhir SMA/SMK yaitu 13 
orang. Pada kelompok treatment pendidikan terakhirnya sebanyak 7 orang $(46,7 \%)$ adalah SMA/SMK dan kelompok kontrol sebanyak 6 orang $(40,0 \%)$ adalah perguruan tinggi dapat dilihat pada tabel 1. Hasil penelitian ini menunjukkan bahwa subjek penelitian rata-rata telah menempuh pendidikan SMA/SMK. Selain itu tingkat pendidikan yang lebih tinggi akan mudah memahami informasi dan mengaplikasikan dalam perilaku dan gaya hidup sehari-hari yang termasuk dalam kepatuhan ${ }^{13}$.

Subjek penelitian sebagian besar tidak bekerja yaitu kelompok treatment 12 orang $(80,0 \%)$ dan kelompok kontrol 6 orang (40,0\%). Hal ini sejalan dengan penelitian Hanum et al. (2015) bahwa mayoritas subjek penelitian tidak bekerja (40\%), mereka mengatakan berhenti bekerja sejak mengetahui dirinya harus menjalani terapi HD secara rutin 2 kali seminggu.

Tabel 2. Distribusi Frekuensi Pengetahuan dan Intake Natrium (Pre-Post Test)

\begin{tabular}{|c|c|c|c|c|c|c|c|c|}
\hline \multirow{3}{*}{ Variabel } & \multicolumn{4}{|c|}{ Treatment } & \multicolumn{4}{|c|}{ Kontrol } \\
\hline & \multicolumn{2}{|c|}{ Pre } & \multicolumn{2}{|c|}{ Post } & \multicolumn{2}{|c|}{ Pre } & \multicolumn{2}{|c|}{ Post } \\
\hline & $\mathrm{N}$ & $\%$ & $\mathrm{~N}$ & $\%$ & $\mathrm{~N}$ & $\%$ & $\mathrm{~N}$ & $\%$ \\
\hline \multicolumn{9}{|l|}{ Pengetahuan } \\
\hline Kurang & 14 & 93,3 & 1 & 6,7 & 15 & 100 & 11 & 73,3 \\
\hline Baik & 1 & 6,7 & 14 & 93,3 & 0 & 0,0 & 4 & 26,7 \\
\hline \multicolumn{9}{|l|}{ Intake Natrium } \\
\hline Lebih & 12 & 80,0 & 7 & 46,7 & 14 & 93,3 & 10 & 66,7 \\
\hline Baik & 3 & 20,0 & 8 & 53,3 & 1 & 6,7 & 5 & 33,3 \\
\hline
\end{tabular}

\section{Pengetahuan}

Berdasarkan tabel 2 peningkatan jumlah responden yang memiliki pengetahuan baik pada kelompok kontrol adalah $26,7 \%$, sedangkan pada kelompok treatment meningkat $86,6 \%$.

Hasil penelitian ini menunjukkan terdapat peningkatan pengetahuan responden tentang pembatasan intake natrium sebelum konseling dan setelah konseling pada kelompok intervensi dan kelompok kontrol, namun pada kelompok treatment perubahannya jauh lebih tinggi karena dilakukan konseling gizi. Hal ini menunjukkan bahwa pemberian konseling gizi dapat meningkatkan pengetahuan dan kemampuan baik individu maupun keluarga sehingga memperoleh pengertian yang lebih baik tentang dirinya serta permasalahan yang dihadapi ${ }^{7}$.

\section{Intake Natrium}

Berdasarkan tabel 2 dapat diketahui bahwa pada awal penelitian hampir semua subjek penelitian dalam kategori lebih. Kemudian setelah dilakukan konseling gizi menggunakan buku saku pada kelompok treatment, kategori baik meningkat yaitu sebanyak 8 orang $(53,3 \%)$, sedangkan 7 orang $(46,7 \%)$ masih masuk dalam kategori lebih. Pada kelompok kontrol yang hanya diberikan buku saku saja, kategori baik juga meningkat yaitu sebanyak 5 orang $(33,3 \%)$, sedangkan 10 orang $(66,7 \%)$ masih dalam kategori lebih. Hasil ini menggambarkan bahwa masih $\geq 40 \%$ subjek penelitian yang tidak patuh pada pembatasan intake natrium.

Tabel 3. Perbedaan pengetahuan pembatasan intake natrium sebelum dan sesudah konseling gizi pada masing-masing kelompok treatment dan kelompok kontrol

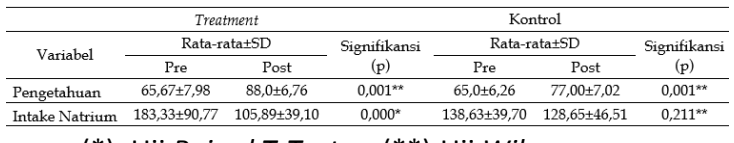

$\left({ }^{*}\right)$ : Uji Paired T-Test $\quad\left({ }^{* *}\right):$ Uji Wilcoxon

\section{Pengetahuan}

Hasil penelitian menunjukkan bahwa ada perbedaan bermakna antara pengetahuan pembatasan intake natrium pada kelompok treatment sebelum dan sesudah konseling gizi menggunakan buku saku $(p=0,001)$. Perbedaan pengetahuan pembatasan intake natrium pada kelompok treatment, menunjukkan bahwa konseling gizi dengan menggunakan buku saku memberikan perubahan pengetahuan pada pasien CKD yang menjalani HD, ini dibuktikan dengan peningkatan nilai rata-rata pengetahuan pada kelompok treatment sebelum penelitian adalah 65,67 dan setelah penelitian 88,00. Sedangkan pada kelompok kontrol berdasarkan analisis statistik menggunakan uji Wilcoxon diperoleh hasil ada perbedaan bermakna antara pengetahuan pembatasan intake natrium setelah diberikan buku saku $(p=0,001)$. Adanya perbedaan pengetahuan pembatasan intake natrium pada kelompok kontrol, menunjukkan bahwa pemberian buku saku memberikan perubahan pengetahuan pada pasien CKD yang menjalani HD, ini dibuktikan dengan peningkatan nilai rata-rata pengetahuan pada kelompok kontrol sebelum penelitian adalah 65,00 dan setelah penelitian 77,00, maka dapat disimpulkan adanya perbedaan yang signifikan antara pengetahuan pembatasan intake natrium sebelum dan sesudah diberikan buku saku. Informasi yang didapatkan melalui media dapat memberikan hal positif mengingat media sebagai bahan pempelajaran berfungsi untuk menyampaikan pesan pada pembaca atau penerima pesan. ${ }^{14}$ Peningkatan pengetahuan pada kelompok kontrol dimungkinkan karena subjek penelitian membaca berulang kali sehingga dapat mempercepat ingatannya. ${ }^{15,16}$

\section{Intake Natrium}


Berdasarkan tabel 3, hasil analisis statistik menggunakan uji Paired T-Test pada kelompok treatment diperoleh hasil ada perbedaan bermakna antara pembatasan intake natrium sebelum dan sesudah konseling gizi menggunakan buku saku $(p=0,000)$. Perbedaan kepatuhan pembatasan intake natrium pada kelompok treatment, menunjukkan bahwa konseling gizi dengan menggunakan buku saku memberikan perubahan kepatuhan pada pasien CKD yang menjalani HD, ini dibuktikan dengan penurunan rata-rata skor intake natrium sebesar $77,44 \mathrm{mg}$ pada kelompok treatment sebelum dan setelah penelitian, maka dapat disimpulkan adanya perbedaan yang signifikan antara intake natrium sebelum dan sesudah pemberian konseling gizi. Sejalan dengan tujuan konseling untuk membantu pasien dalam upaya mengubah perilaku yang berkaitan dengan gizi sehingga meningkatkan kualitas gizi dan kesehatan pasien. Penilaian konseling yang efektif adalah komunikasi dua arah yang memungkinkan terjadinya perubahan perilaku. ${ }^{7}$ Sedangkan pada kelompok kontrol berdasarkan analisis statistik menggunakan uji Wilcoxon diperoleh hasil tidak ada perbedaan bermakna antara intake natrium setelah diberikan buku saku $(p=0,211)$. Pembatasan intake natrium sebelum dan sesudah diberikan buku saku tidak adanya perbedaan menunjukkan bahwa kemungkinan terjadi karena pada kelompok kontrol yang tidak diberikan konseling masih ada yang tidak patuh pada pembatasan intake natrium. Dalam proses konseling seseorang yang membutuhkan pertolongan (pasien) dan seorang petugas konseling akan bertatap muka dan berbicara hingga pasien mampu untuk memecahkan masalah yang dihadapinya. ${ }^{7}$

Tabel 4. Perbedaan Pengetahuan dan Intake Natrium Sebelum dan Sesudah Konseling Gizi antara Kelompok Treatment dan Kelompok Kontrol

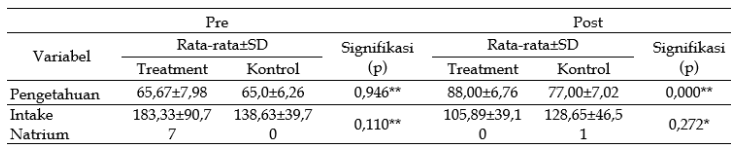

$\left({ }^{*}\right)$ : Uji Independent T-Test $\left({ }^{* *}\right)$ :Uji Mann Whitney

\section{Perbedaan pengetahuan antara kelompok treatment dan kontrol \\ Tabel 4 menunjukkan bahwa} pengetahuan tentang pembatasan intake natrium antara kelompok treatment dan kelompok kontrol sebelum penelitian tidak berbeda $(p=0,949)$, sedangkan sesudah penelitian ada perbedaan pengetahuan bermakna antara kelompok treatment dan kelompok kontrol $(p=0,000)$.

\section{Perbedaan intake natrium antara kelompok} treatment dan kontrol

Tabel 5. Menunjukkan bahwa tidak ada perbedaan intake natrium antara kelompok treatment dan kelompok kontrol sebelum penelitian $(p=0,110)$ dan sesudah penelitian $(p=0,272)$.

Tabel 5. Pengaruh Konseling Gizi terhadap Pengetahuan dan Intake Natrium pada Kelompok Treatment dan Kelompok Kontrol

\begin{tabular}{|c|c|c|c|}
\hline Variable & Kelompok perlakuan & $\begin{array}{l}\text { Nilai rata - rata } \\
\text { perubahan }\end{array}$ & $\begin{array}{l}\text { Signifikasi } \\
\text { (p) }\end{array}$ \\
\hline \multirow[t]{2}{*}{ Pengetahuan } & Kontrol & \multirow{2}{*}{\multicolumn{2}{|c|}{12}} \\
\hline & Intervensi & & \\
\hline \multirow[t]{2}{*}{ Intake Natrium } & Kontroll & -9.9 & \multirow{2}{*}{$0.001^{*}$} \\
\hline & Intervensi & -77.4 & \\
\hline
\end{tabular}

(*):Uji Independent T-test(**):Uji Mann Whitney

Penelitian pengetahuan tentang pembatasan intake natrium dilakukan uji statistik dengan menggunakan uji Mann Whitney diperoleh hasil ada perbedaan bermakna antara pengetahuan pembatasan intake natrium sebelum dan sesudah konseling gizi pada kelompok treatment dan kelompok kontrol, hal ini dibuktikan nilai $p<0,05(p=0,001)$, dapat dilihat pada tabel 9 . Adanya perbedaan antara pengetahuan pembatasan intake natrium sebelum dan sesudah konseling gizi pada kelompok treatment dan kelompok kontrol, menunjukkan bahwa perubahan dalam peningkatan pengetahuan yang lebih tinggi pada kelompok treatment yaitu 22,3 dibandingkan dengan kelompok kontrol hasilnya adalah lebih renda yaitu 12 . Hasil ini dapat disimpulkan ada perbedaan pengetahuan secara signifikan terhadap pembatasan intake natrium sebelum dan sesudah konseling gizi pada kelompok treatment dan kelompok kontrol. Sejalan dengan penelitian Hanum et al. (2015) yang meneliti pengaruh pendidikan kesehatan secara individual tentang pembatasan intake yang dilakukan dengan menggunakan media memberikan hasil perubahan yang lebih meningkat dibandingkan dengan penyampaian materi hanya menggunakan media. Hal ini karena jika diberikan secara individual menghasilkan kontak antar penerima dan pemberi pesan menjadi lebih intensif, sehingga pasien dengan sukarela, berdasarkan kesadaran dan penuh pengertian akan menerima informasi yang diberikan ${ }^{17}$.

Pada awal penelitian pembatasan intake natrium dilakukan uji statistik dengan menggunakan uji Independent T-Test diperoleh 
hasil ada perbedaan bermakna antara kepatuhan pembatasan intake natrium sebelum dan sesudah konseling gizi pada kelompok treatment dan kelompok kontrol, hal ini dibuktikan nilai $p<0,05$ $(p=0,001)$, dapat dilihat pada tabel 9. namun terjadi peningkatan kepatuhan yang lebih tinggi pada kelompok treatment yaitu 77,4 kemudian dibandingkan dengan kelompok kontrol hasilnya adalah lebih rendah 9,9. Adanya perbedaan antara pengetahuan pembatasan intake natrium sebelum dan sesudah konseling gizi pada kelompok treatment dan kelompok kontrol, menunjukkan bahwa kemungkinan terjadi karena pada kelompok kontrol yang telah diberikan konseling masih ada yang tidak patuh pada pembatasan intake natrium. Keberhasilan konseling itu sendiri tergantung dari berbagai faktor, baik faktor internal (pendidikan, keahlian, persepsi) maupun eksternal (lingkungan, organisasi, social budaya, sosioekonomi) ${ }^{4}$.

\section{KESIMPULAN}

Berdasarkan hasil analisis secara full model menunjukkan bahwa Pemberian konseling gizi menggunakan buku saku berpengaruh meningkatkan pengetahuan dan menurunkan intake natrium $(p=0,001$ dan $p=0,001)$. Pengetahuan responden kelompok intervensi meningkat $22,33 \%$ dan penurunan asupan natrium sebesar $77,4 \%$.

\section{SARAN}

Perlu penelitian lebih lanjut mengenai dukungan keluarga untuk memantau makanan yang dikonsumsi pasien hemodialisa khususnya yang mengandung tinggi natrium.

\section{DAFTAR PUSTAKA}

1. World Kidney Day. World Kidney Day. International Urology and Nephrology. 2015;

2. Jha V, Garcia-Garcia G, Iseki K, Li Z, Naicker S, Plattner B, et al. Chronic kidney disease: Global dimension and perspectives. Lancet. 2013;382(9888):260-72.

3. NIDDK. Treatment Methods for Kidney Failure: Hemodialysis. 2010;

4. Octa P I, Tjahjono D.K. K, Nuggetsiana S A. Pengaruh Frekuensi Konseling Gizi dan Gaya Hidup Terhadap Indeks Massa Tubuh, Lingkar Pinggang, Tekanan Darah, dan Glukosa Darah pada Penderita Diabetes Mellitus. 2011;1-19.

5. Umayah E. Hubungan Tingkat Pendidikan, Pengetahuan dan Dukungan Keluarga dengan Kepatuhan dalam Pembatasan Asupan Cairan pada Pasien Gagal Ginjal Kronik (GGK) yang
Menjalani Hemodialisa (HD) Rawat Jalan di RSUD Kabupaten Sukoharjo. Skripsi, Universitas Muhamadiyah Surakarta; 2016.

6. Setia Rini, Siti Rahmalia HD APD. Hubungan antara Dukungan Keluarga terhadap Kepatuhan dalam Pembatasan Asupan Nutrisi dan Cairan pada Pasien Gagal Ginjal Kronik dengan Hemodialisa. Progr Stud IImu Keperawatan Univ Riau. 2013;16-8.

7. Cornelia, Sumedi E dkk. Konseling Gizi. 3rd ed. Jakarta: Penebar Swadaya Grup; 2016. 9$42 \mathrm{p}$.

8. Kamaluddin R, Rahayu E. Analisis FaktorFaktor yang Mempengaruhi Kepatuhan Asupan Cairan pada Pasien Gagal Ginjal Kronik dengan Hemodialisis di RSUD Prof. Dr. Margono Soekarjo Purwokerto. J Keperawatan Soedirman. 2009;4(1):20-5.

9. Sucipto A. Efektivitas Konseling DM Dalam Meningkatkan Kepatuhan Diet DM pada Diabetes Melitus Tipe 2. Med Respati. 2014;

10. Hanum R, Nurchayati S, Hasneli Y. Pengaruh Pendidikan Kesehatan secara Individual tentang Pembatasan Asupan Cairan terhadap Pengetahuan tentang Pembatasan Cairan dan IDWG (Interdialytic Weight Gain) pada Pasien Hemodialisis. Jom. 2015;2(2):1427-34.

11. Indonesia Renal Registry. 7 th Report Of Indonesian Renal Registry 20147 th Report Of Indonesian Renal Registry 2014. Indonesia Renal Registry. 2014.

12. Aurora RG, Sinambela A, Noviyanti CH. Peran Konseling Berkelanjutan pada Penanganan Pasien Hiperkolesterolemia. J Indon Med Assoc. 2012;62(5):194-201.

13. Fatmah Mardjun, Zuhriana K. Yusuf AA. Faktor yang Berhubungan dengan Kepatuhan Pembatasan Asupan Cairan pada Pasien Gagal Ginjal Kronik di Ruang Hemodialisa RSUD Prof. Dr. H. Aloei Saboe Kota Gorontalo. Doctoral dissertation. Doctoral dissertation, Universitas Negeri Gorontalo; 2014.

14. Simamora RH. Buku Ajar Pendidikan dalam Keperawatan. Tiar E, editor. Jakarta: EGC; 2009. 64-73 p.

15. Larasari P. Pengaruh Konseling dengan Bantuan Media Leafleat terhadap Pengetahuan Penggunaan Antibiotik pada Masyarakat Patrang Kabupaten Jember. Skripsi, Universitas Jember; 2015

16. Kawuriansari R, Fajarsari D, Mulidah S. Studi Efektifitas Leaflet Terhadap Skor Pengetahuan Remaja Putri Tentang Disminorea di SMP Kristen 01 Purwokerto Kabupaten Banyumas. J Bidan Prada. 2010;1(1):108-22. 
17. Notoatmodjo S. Kesehatan Masyarakat : Ilmu \&

Seni. Jakarta: Rineka Cipta; 2007. 144 p 